\section{ECONOMICS}

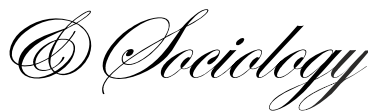

\title{
DEVELOPMENT OF CONTROLLERS' PROFESSIONAL COMPETENCE: THE CASE OF CZECH REPUBLIC
}

Prague, Czech Republic,

E-mail:kral@vse.cz.

Libuše Šoljaková,

Management Accounting

Department,

University of Economics,

Prague, Czech Republic,

E-mail: soljak@vse.cr.

Received: July, 2015

1st Revision: October, 2015

Accepted: December, 2015

DOI: $10.14254 / 2071-$

789X.2016/9-1/6

JEL Classification: M21

Keywords: controller, professional competence, education, skills, experience, quality assurance.

\begin{abstract}
The paper describes the results of the project on generally accepted requirements to controllers professional competence development. The empirical research is to ascertain and evaluate the current situation in Czech Republic in this area.

The research comes from the comparison of two groups of experts' opinions: firstly, the respondents responsible for professional competence development of controllers, and secondly, managers and controllers actually doing business.

The article analyses and comments on the results of the following areas of investigation: content of controllers' activities, controllers' authority and responsibility, requirements for their initial education, professional skills and practical experience, ethical aspects of their activities, selection of potential candidates for a controller position, requirements to their continuing professional development and quality assurance of controllers' work.
\end{abstract}

\section{Introduction}

One of the problem areas which has changed in its qualitative substance is how companies are managed. All functions of company management have been in movement, including the instruments, methods and information support used (Král, Šoljaková, 2015).

These changes have their reflection in many aspects of business. Among other things, they have also impact on qualitative aspects of controllers' work. This is demonstrated especially by:

- newly formulated requirements of companies on their work; and

- the reactions of business schools, universities and accounting-oriented professional bodies which must respond to these changes by implementing new requirements into business schools' and university curricula and into certification systems which is broadly understood here as professional competence development of controllers.

In this regard, the aim of this paper is to describe a project the general purpose of which was to define and analyse the requirements to professional competence development of controllers. 
The project was initiated in 2011 by the International Group of Controlling. However, shortly after the definition of the first version of the conceptual outcomes it was stopped as an international project with the recommendation to national professional bodies to implement it on the national bases first.

Czech version of the project has been running since the beginning of 2012 at the Management Accounting Department of the Faculty of Finance and Accounting of the University of Economics, Prague. The research team has been drawn on the International Group of Controlling (2010, 2011) conceptual outcomes and it has been extended them along two lines:

- by developing a revised project framework; and

- by conducting an empirical research,the e aim of which has been to map the most important requirements to professional competences of controllers in Czech Republic.

The aim of the following stageundertaken in 2015 was to compare the results of Czech empirical research with the results in other countries.

The paper describes and evaluates the results of the empirical research focused on the changing requirements to controllers' work in Czech Republic.

\section{Literature review}

Although the topic which is the subject of our investigation is not elaborated in the papers devoted to the controllers' professional competency development exclusively, some papers document the importance of controllers' professional competence in broader circumstances. The following sources were considered to be relevant; they are ordered from the most general to more specific ones.

Many researchers (for example Merchant, 2003; Kaplan and Cooper, 1998; Burns and Yazdifar, 2001) confirm the crucial role of good company management in the changing business environment. The most important factors influencing the management include its inter-disciplinary nature, strategic perspective, its multidimensionality, and the integration of inter-relationships (but also divergence) between the user and data processing areas of quality information systems (Simons, 2004; Parker, 2002; Merchant, 2003).

This situation has a significant impact not only on the substance of the company management control system, including its information support (Carruth, 2004), but also on the professional education, skills, knowledge, experience and ethical approaches, values and attitudes of financial managers.

Some authors devote special attention to controllers or managerial accountants whose professional competence is the principal subject of our investigation. For example Kaplan (1998) states that the changes in company management accompanied by ICT development enable these professionals to be liberated from routine data processing, which gives them the opportunity to

- $\quad$ spend less time on standardized statements;

- devote more attention to analyses and interpretation of submitted information;

- communicate companies' goals and how to accomplish them to those people from departments who are responsible for their achievement;

- shift the focus of their work away from comparing the actual and desired company results and towards decision-making about the future course of the business process.

Some recent papers (CIMA, 2008, 2009) argue that correct decision-making is becoming a basis for competitive advantage and value creation; controllers should play key role in the decision-making. The main challenge facing finance and accounting is how to develop controllers who will be able to collaborate with the business managers and support their decision-making. 
Zralý (2007) analyses the changing role of managers, controllers and managerial accountants and the interactions among them and comes to a conclusion that all these professionals should follow the approach which he calls the "controlling convergent concept".

Grandlund and Lukka (1998) stress that management accountants should not act only as information support providers, but more as business partners to managers.

All the above-stated changes in the content of management accountants' work have influenced new requirements for their professional competence. Before, they were required to have good knowledge, hard and soft skills and experience of the management accounting instruments and methods, and their implementation and use in the company information systems. Currently, they are rather expected to be competent to use this knowledge, skills and experience for the purpose of integrating management accounting information with other nonfinancial information on an interdisciplinary basis. They should be able to justify, interpret and present the results for the whole company as well as its sections, to assure quality information support for decision-making and to be able to strengthen companies' synergistic effects through the communication and integration of the relations they develop and cultivate (see for example Burns and Yazdifar, 2001; Yasin, 2005; Hoper, 1980; Horváth, 2006; and Zralý, 2007).

Moreover, according to many researchers (see for example: Pierce and O’Deam, 2003; Grandlund and Lukka, 1998; Jablonsky, Keating and Heian, 2004 and Yasin, Bayes, Czuchry, 2005) the ability to argue, interpret and present results and to connect accounting information with intangible and "invisible" sections of business activities and other so called soft skills are more and more important.

According to others (see for example: Yasin et al., 2005; Pierce and O'Deam, 2003; Grandlund and Lukka, 1998; Jablonsky et al., 2004) it is crucial to stress the necessity to perceive, support and communicate ethical and moral values, approaches and attitudes as the factors which have been undervalued in all frequently quoted materials devoted to professional competence development of controllers as well as in practice.

\section{Research methodology}

In similar projects which comprise general and practical parts of investigation, it is sometimes appropriate to divide research methodology of the whole project into two parts into the first one which was used primarily in the general part of the project, and the second one which was used especially in the empirical part of the research which is the subject of this paper. However, in this case, due to the integration of both parts it is necessary to describe shortly the methodology of the whole project.

Comparison is the principal research method used throughout the whole project. The following three kinds of comparisons were carried out:

- Comparison of existing standards which define requirements for the controllers' professional competence with the literature sources which are interested in the impact of business environment changes on the professional competence of these experts. This type of comparison has been used especially in the conceptual part of the research; nevertheless the results were also used to develop the structure and content of the questionnaire.

- Comparison of these developing tendencies with recent practise in selected, relatively large companies.

- Comparison of how this practise is perceived and implemented

$\circ$ by those experts who are responsible for the controllers' professional competence development, and

$\circ$ by those who actually operate in a business. 
These types of comparison were used especially in the selection of two groups of the addressed respondents.

Other methods used when solving the project include:

- descriptive methods used mainly to determine the requirements for controllers' professional competence development;

- statistical methods used to express trends and relations which are the subject of the investigation in the empirical part of the project;

- synthesis and analysis used when considering the aims, content and structure of the questionnaire;

- analogy used during the questionnaire development, especially in the parts devoted to education, skills and practical experience requirements on a controller; and

- generalization used when formulating the principal project outcomes.

All the above stated methods are integrated in a system approach. It is used in the following three ways:

- In the content and structure of the investigated topic where it was the aim of the research team to analyse all substantial values of the controllers' professional competence, in the first stage as individual elements and in the second stage - on the basis of synthesis - in their mutual inter-relations;

- In the expression of inter-relations between the analysed elements and the project outcomes; and

- In the integration of general and empirical parts of the project.

The aim of the empirical part of the research project, which followed the conceptual outcomes, was to map how the general tendencies manifest themselves in the practical requirements on professional competence of controllers. In order make this comparison, two groups of respondents were addressed:

- experts who works at business schools, universities, initial education and exam departments of professional bodies and who are responsible for controllers' competence development in the initial stage;

- managers and controllers operating in companies who perceive the requirements on the controllers' professional competence through the eyes of business reality.

This was the reason why the questionnaire was developed in two versions:

- a version concisely titled "A controller should be...", designated for the first group of experts; and

- a version concisely titled “A controller is...”, designated for the second group.

The respondents in the second group have been managers or controllers of randomly selected Czech as well as foreign companies in various industries operating in the Czech Republic with the number of employees exceeding 100 and with the annual sales over $€ 50 \mathrm{~m}$.

Both versions of the questionnaire were nearly identical regarding their structure and content. They were based on the conceptual outcomes formulated in the previous stage of the research project and contained mostly questions which required the respondents to rate on a scale from 1 (strong disagreement) to 5 (strong agreement). Only a small part of the questionnaires required Yes or No or open answers.

The questionnaires comprised questions based on the following problem areas:

- The position of controllers in the companies' organizational charts;

- The structure of departments of controllership;

- The relationship of these departments to other financial management departments;

- The general content of the controllers' activities;

- The areas and extent of the controllers' authority and responsibility;

- The specific content of the controllers' activities; 
- Requirements for education;

- Requirements for professional skills and practical experience;

- Controllers' role in ethical aspects of business;

- Selection of potential candidates for a controller / management accountant positions;

- Controllers' continuing professional development; and

- Quality assurance of the controllers' work.

To assure reliable and relevant data, the research team divided the work on the questionnaire into two stages:

- The final aim of the first stage was to verify the completeness and understandability of the questionnaires in individual interviews; 21 respondents from the first group and 5 respondents from the second group participated in this stage of the questionnaires' development; and

- On the basis of this phase, both versions of the questionnaire were developed into the form which was appropriate for their electronic distribution.

\section{Empirical research results}

The empirical part of the research is in the stage in which:

- 27 participants responded to the questions of “A controller should be ...” questionnaire; and

- 74 participants responded to the questions of "A controller is ..." questionnaire.

The analysis of the responses brought the following results.

\subsection{Controllers' position in the companies' organizational charts}

The research so far has not given an unambiguous response regarding the question of controllers' position in the organizational charts of the selected companies and related questions about the desired structure of the departments which should assure controllers' functions or their relations to the other departments engaged in various aspects of the companies' financial management.

In our view, this is not caused only by the difficult generalization of progressive tendencies, but also by the different Anglophone and Germanic approaches to these questions which are applied in the companies operating in the Czech Republic.

However, most respondents supported (described) a solution in which controllers

- Are members of the department supervised by the company CFO; and

- They should not (do not) have straight-line authority and responsibility in the company management issues.

This concept is in the compliance with Horváth's understanding of controllers as "the economic conscience of a company” (Horváth, 2006).

\subsection{General content of the controllers' activities}

As far as the general content of the controllers' activities is concerned, the investigation showed that both groups of experts were almost unanimous in their listing as well as in their evaluation of the importance of individual activities. According to the responses, controllers are exclusively responsible for the correctness of input data, the efficiency of their processing into the output information and the successive quality, availability and transparency of the information rendered to managers. 
In compliance with the above stated role of a controller as the economic conscience, both groups of experts also agreed that a controller should not bear primary responsibility for the company's financial results. The responses of the second group of experts, however, show slightly higher average and mode.

In our view, it is possible to explain this difference in a sense that:

- While the first group generally rejects the responsibility for financial results,

- In practice, controllers gain a certain part of their bonuses based on these results.

In our opinion, this difference is probably given by the fact that many companies tie (quite correctly) bonuses of their employees (including controllers) to financial results with the aim to communicate interest in their fulfilment across all company levels, regardless of whether their employees directly influence them or not.

The numerical outcomes of the investigation are stated in Table 1.

Table 1. General content of controllers’ activities

\begin{tabular}{lcccc}
\hline & \multicolumn{2}{c}{ "Should be" } & \multicolumn{2}{c}{ "Is" } \\
\cline { 2 - 5 } & Average & Mode & Average & Mode \\
\hline $\begin{array}{l}\text { Correctness of data processed subsequently into the } \\
\text { output information used in managerial control }\end{array}$ & 3.92 & 5 & 4.46 & 5 \\
\hline $\begin{array}{l}\text { Quality of information rendered to company } \\
\text { management }\end{array}$ & 4.46 & 5 & 4.26 & 5 \\
\hline Availability of information for company management & 4.13 & 5 & 3.94 & 5 \\
\hline $\begin{array}{l}\text { Transparency of information rendered to company } \\
\text { management }\end{array}$ & 4.54 & 5 & 4.12 & 4 \\
\hline Financial results & 2.0 & 1 & 2.69 & 2 \\
\hline
\end{tabular}

Source: authors' calculations.

\subsection{Controllers' authority and responsibility}

Following general content of controllers' activities, the questionnaire also investigated areas of the controllers' authority and responsibility.

The comparison of both versions of the questionnaire shows the experts' general agreement with the opinion that a controller is (should be) equipped with a sufficient authority and responsibility in the areas in which he/she serves as:

- An expert preparing scenarios of future solutions for managers;

- A methodist who is responsible for the pricing, costing, budgeting and management accounting development (including the terminology used) and who should also devote attention to their adherence;

- An expert facilitating and supporting communication and coordination between all company management levels;

- A communicator who transfers reached results to the relevant management levels and who comments, explains and interprets these results to managers; and finally;

- An expert who participates in the regulation and support of the company financial management development including the system of remuneration and motivation.

Both groups also agreed on the conclusion that a controller should not have the authority to influence source allocation (e.g. he/she should not decide about the volume and structure of sold products, accept or refuse make-or-buy decisions or to decide about the extension or reduction of customer or distribution channels). 
In some areas, however, it is also apparent the opinions of both groups differ. The first of them is the area of coordination of activities connected with formulation of the company objectives and means of their fulfilment. According to the first group of respondents, the role of these experts is very important in this area, however, according to the second group, controllers do not play such an important role in practise. In their view, controllers are more focused on the technical and methodological activities of controllership (including information support), and they are not involved so much in the substantial questions of strategy formulation and implementation.

Also, there was low agreement between both groups of respondents regarding whether a controller should act (acts) as an originator of management information system or its parts.

The numerical outcomes of the investigation are stated in Table 2.

Table 2. Areas of authority and responsibility

\begin{tabular}{|c|c|c|c|c|}
\hline & \multicolumn{2}{|c|}{ "Should be" } & \multicolumn{2}{|c|}{ "Is" } \\
\hline & Average & Mode & Average & Mode \\
\hline $\begin{array}{l}\text { Coordination of activities connected with formulation of } \\
\text { the company objectives and means of their fulfilment }\end{array}$ & 4.29 & 5 & 3.03 & 3 \\
\hline Preparation of scenarios of future solutions & 4.21 & 5 & 3.28 & 3 \\
\hline Development of an information system or its parts & 3.67 & 4 & 3.13 & 3 \\
\hline $\begin{array}{l}\text { Development of directives on pricing, costing, } \\
\text { budgeting and management accounting development } \\
\text { and examination of adherence to them }\end{array}$ & 3.91 & 5 & 3.74 & 4 \\
\hline $\begin{array}{l}\text { Communication of results reached to relevant } \\
\text { management levels }\end{array}$ & 4.33 & 5 & 4.21 & 5 \\
\hline $\begin{array}{l}\text { Explanation and interpretation of information rendered } \\
\text { to managers }\end{array}$ & 4.54 & 5 & 4.37 & 5 \\
\hline $\begin{array}{l}\text { Facilitation and support of communication between } \\
\text { departments }\end{array}$ & 3.54 & 5 & 3.24 & 3 \\
\hline Decision on resource allocation & 1.79 & 1 & 2.19 & 1 \\
\hline $\begin{array}{l}\text { Participation in the regulations of a company’s financial } \\
\text { management development including the system of } \\
\text { remuneration and motivation }\end{array}$ & 3.42 & 4 & 2.81 & 3 \\
\hline
\end{tabular}

Source: authors' calculations.

\subsection{Specific content of the controllers' activities}

In the specific content of the controllers' activities investigation, the research has acknowledged the crucial role of controllers in ensuring the companies' target information, i.e. in planning and budgeting on the strategic, tactical and operational levels, including processing, presentation and explanation of forecasts, estimates and expectations.

The respondents have also stressed the crucial role of "traditional controllers' task" adequate information support for acquisition of business resources (fixed assets, inventories, human resources etc.) and management of business processes (research and development, purchasing, production, logistics, production, sale etc.).

There is substantially lower agreement between both groups - surprisingly for us regarding controllers' role and participation in the development of management accounting and connected internal reporting system. The respondents also have not found agreement in response to the question "To what extent should controllers bear responsibility for the quality 
of company project management, risk identification and management and organization structures development?"

Respondents of both groups have also answered differently to the question whether a controller should assure (assures) quality information support in the areas of business resources acquisition and management of business processes. However, this difference can be - in our opinion - caused by the sample of respondents; after a more detailed analysis we have ascertained, the companies included in this pilot part of the research have a relatively simple business cycle and these factors have not related to them.

The results of this part of the investigation are stated in Table 3.

Table 3. Specific content of the controllers' activities

\begin{tabular}{lcccc}
\hline & \multicolumn{2}{c}{ "Should be" } & \multicolumn{3}{c}{ "Is" } \\
\cline { 2 - 5 } & Average & Mode & Average & Mode \\
\hline Strategic planning and budgeting & 4.29 & 5 & 4.13 & 5 \\
\hline Tactical planning and budgeting & 4.21 & 5 & 4.12 & 5 \\
\hline Operational planning and budgeting & 4.04 & 4 & 4.07 & 5 \\
\hline Expectations and forecasts development & 4.29 & 5 & 4.46 & 5 \\
\hline $\begin{array}{l}\text { Communication of results reached to relevant } \\
\text { management levels }\end{array}$ & 4.33 & 5 & 4.12 & 5 \\
\hline $\begin{array}{l}\text { Participation in the development of management } \\
\text { accounting and internal reporting systems }\end{array}$ & 4.00 & 4 & 4.12 & 5 \\
\hline $\begin{array}{l}\text { Participation in the development of the project } \\
\text { management system }\end{array}$ & 3.54 & 3 & 2.57 & 3 \\
\hline $\begin{array}{l}\text { Participation in the development of the risk identification } \\
\text { and management system }\end{array}$ & 3.33 & 3 & 2.79 & 4 \\
\hline $\begin{array}{l}\text { Information support for acquisition of business resources } \\
\text { and management of processes (research and } \\
\text { development, purchasing, production, logistics, sale etc.) }\end{array}$ & 4.17 & 5 & 3.44 & 2 \\
\hline $\begin{array}{l}\text { The development and enhancement of organization } \\
\text { structures including follow-up activities }\end{array}$ & 2.88 & 3 & 2.33 & 1 \\
\hline
\end{tabular}

Source: authors' calculations.

\subsection{Requirements for education}

The requirements on the controllers' education formed a substantial part of both questionnaires. In this section, the questionnaires were based on the structure of requirements defined by

- IFAC International Education Standards, and

- UNCTAD Revised Model Accounting Curriculum.

The aims, content and structure of the pre-qualification programmes of the Chamber of Auditors, Czech Republic, the Union of Accountants and the ACCA, and syllabuses of the master-degree specializations of Accounting and Company Financial Management and Controllership taught at the Faculty of Finance and Accounting of the University of Economics, Prague were also taken into the consideration.

As it can be seen from Table 4, both groups of respondents have stressed the importance of knowledge of financial accounting and reporting, management accounting and corporate finance. Surprisingly for us, the second group even preferred knowledge of financial accounting over knowledge of management accounting. According to both groups of experts, knowledge of taxation, internal control systems, information and communication 
technology and business administration are other areas of controllers' knowledge relevant to their work.

Conversely, knowledge of law, auditing, marketing and international aspects of business are not so important for controllers' activities according to both groups of experts.

Table 4. Requirements for education

\begin{tabular}{lcccc}
\hline \multirow{2}{*}{$\begin{array}{l}\text { Controller should be able to use knowledge from the } \\
\text { following areas: }\end{array}$} & \multicolumn{2}{c}{ "Should be" } & \multicolumn{2}{c}{ "Is" } \\
\cline { 2 - 5 } & Average & Mode & Average & Mode \\
\hline Financial accounting and reporting & 4.71 & 5 & 4.59 & 5 \\
\hline Management accounting & 4.92 & 5 & 4.49 & 5 \\
\hline Corporate finance & 4.63 & 5 & 4.20 & 5 \\
\hline Taxation & 3.79 & 4 & 3.06 & 3 \\
\hline Business law & 3.17 & 3 & 2.46 & 2 \\
\hline Labour law & 2.83 & 3 & 2.25 & 2 \\
\hline Social and health insurance law & 2.75 & 3 & 2.33 & 2 \\
\hline Auditing & 3.42 & 4 & 3.03 & 3 \\
\hline Internal control systems & 3.96 & 5 & 3.53 & 4 \\
\hline Economics & 3.25 & 3 & 3.74 & 4 \\
\hline Management & 3.75 & 3 & 3.26 & 4 \\
\hline Business administration & 4.21 & 5 & 4.00 & 5 \\
\hline Marketing & 2.79 & 3 & 2.16 & 2 \\
\hline Quantitative methods (Mathematics, Statistics) & 3.58 & 4 & 3.21 & 3 \\
\hline International aspects of business & 2.88 & 3 & 2.73 & 3 \\
\hline Information and communication technology (ICT) & 3.75 & 3 & 3.27 & 3 \\
\hline
\end{tabular}

Source: authors’ calculations.

\subsection{Requirements for ICT competencies}

Although ICT knowledge formed one of the sections of the requirements for education, special part of the questionnaire was also devoted to ICT competencies. The reason is apparent: All companies' as well as controllers' activities take place in ICT environment, it is not possible to realise all the above stated duties and responsibilities without ICT knowledge, the crucial impact of ICT on controllers' work was stressed in many of the abovementioned literature sources.

Generally, the responses of both groups of respondents acknowledged the fact that the fast development of ICT has changed the substance of controllers' work and - conversely controllers are required more and more to participate actively in the development of the companies' ICT systems.

Concerning more specific areas of research, the aim of both versions of the questionnaire was to define the controllers' role(s) in the area of ICT: the respondents have been asked whether controllers (should) act as users of ICT only or whether they (should) also participate actively in ICT development. According to both groups' responses, controllers are considered to be ICT users rather than originators and verifiers of processing and user quality. Both groups also agreed with the statement that controllers should not serve (do not serve) as managers of ICT projects.

The results of this part of investigation are stated in Table 5. 
Table 5. ICT competencies

\begin{tabular}{lcccc}
\hline \multirow{2}{*}{ In the area of ICT a controller acts especially as } & \multicolumn{2}{c}{ "Should be" } & \multicolumn{2}{c}{ "Is" } \\
\cline { 2 - 5 } & Average & Mode & Average & Mode \\
\hline User (with stress on areas he/she uses) & 4.26 & 5 & 4.48 & 5 \\
\hline Creator (with stress on areas he/she uses) & 3.30 & 4 & 3.25 & 4 \\
\hline Originator or verifier of processing quality & 3.70 & 3 & 3.13 & 3 \\
\hline Originator or verifier of user quality & 3.91 & 4 & 3.51 & 4 \\
\hline Manager of ICT projects or their parts & 2.71 & 2 & 2.91 & 3 \\
\hline
\end{tabular}

Source: authors' calculations.

\subsection{Requirements for professional skills and practical experience}

The investigation also focused on professional skills and practical experience which controllers (should) acquire to be able to act competently. The structure of these skills was derived from their overview stated especially in IFAC International Education Standard 3 Professional skills.

As it is apparent from the following Table 6, both groups of experts consider all the stated soft skills as relatively very important for controllers' work - although they evaluate the first three ones as being even more important than the rest.

Table 6. Requirements for professional skills and practical experience

\begin{tabular}{lcccc}
\hline \multirow{2}{*}{ It is important for a controller to develop especially } & \multicolumn{2}{c}{ "Should be” } & \multicolumn{2}{c}{ "Is" } \\
\cline { 2 - 5 } & Average & Mode & Average & Mode \\
\hline Communication skills & 4.38 & 5 & 4.10 & 4 \\
\hline $\begin{array}{l}\text { Ability to deal with people and assert his/her } \\
\text { opinions }\end{array}$ & 4.46 & 5 & 4.06 & 4 \\
\hline Presentation skills & 4.58 & 5 & 4.22 & 4 \\
\hline Managerial and organizational skills & 3.63 & 3 & 3.79 & 3 \\
\hline Language knowledge including ability to use it & 3.57 & 3 & 3.63 & 4 \\
\hline
\end{tabular}

Source: authors' calculations.

Special part of the questionnaires was devoted to the question whether respondents value higher educational pre-conditions or soft skills: in this regard it was interesting that the experts in the first group consider soft skills even more important than respondents in the second group. In our view, the principal reason for this is the fact that, up to now, adequate attention has not been devoted to the development of controllers' (financial managers and professional accountants) soft skills and - consequently - their level and quality do not reach the required level yet in the Czech Republic. Another explanation for the lack of education can also be the fact that managers operating in business are still not convinced about their importance.

\subsection{Controllers' role in ethical aspects of business}

Regarding ethical aspects of business, both groups of respondents generally agree with the statement that - despite the fact that this area was undervalued for a long time - recently it has been very important for a company to define, enhance, support and communicate effectively ethical principles and rules of how they are carried out. 
In contrast to this general belief, our investigation found relatively low level of practical application of ethical principles and rules in recent company life. This fact is visible from the comparison of both groups of respondents to all statements of this section (all responses of the "Is" group respondents show lower level of agreement than the responses of "Should be" group). However, it is especially apparent from the comparison of both groups' reactions to the question, whether a controller participates in the development of ethical company standards, codes and guidelines: according to the first group of respondents, it is very important to incorporate ethical standards into a company guidelines and codes. Nevertheless, this general requirement is not fulfilled in practise.

As it is also apparent from the following table, the role of controllers in the process of ethical principles enforcement is very unsatisfactory. While the first group of respondents (and also all standards and guidelines devoted to ethical aspects of professional accountants' activities) evaluate this section of controllers' work as quite important, according to the second group of experts' responses, in practice controllers do not support fulfilment of ethical standards at all.

The results of this part of investigation are stated in Table 7.

Table 7. Controllers' role in ethical aspects of business

\begin{tabular}{lcccc}
\hline & 4.58 & 5 & 4.13 & 5 \\
\cline { 2 - 6 } & Average & Mode & Average & Mode \\
\hline $\begin{array}{l}\text { It is important for a company to define, enhance, } \\
\text { support and communicate effectively the ethical } \\
\text { principles and rules of business }\end{array}$ & 4.50 & 5 & 3.90 & 5 \\
\hline $\begin{array}{l}\text { These principles and rules are explicitly incorporated } \\
\text { into company standards, codes and guidelines }\end{array}$ & 3.63 & 4 & 2.49 & 3 \\
\hline $\begin{array}{l}\text { Controller participates in the development of ethical } \\
\text { company standards, codes and guidelines }\end{array}$ & 3.38 & 3 & 3.16 & 4 \\
\hline $\begin{array}{l}\text { In the scope of his/her authorities and responsibilities, } \\
\text { the controller participates in the inspection of how these } \\
\text { standards, codes and guidelines are fulfilled }\end{array}$ & & & & \\
\hline $\begin{array}{l}\text { Controller serves as an informal authority in the } \\
\text { fulfilment of these standards, codes and guidelines - in } \\
\text { the internal company environment as well as externally }\end{array}$ & 3.38 & 5 & 2.68 & 1 \\
\hline
\end{tabular}

Source: authors' calculations.

\subsection{Human resources management}

The section "human resources management" focused on two problem areas:

- The selection of potential candidates for a controller position; and

- The importance of their continuing professional development.

Especially in the first section, there is a great level of agreement between both groups of respondents in reaction to all statements.

Both groups believe that education and practical experience are more relevant than controllers' personal values and communication skills; however, the difference is very small and confirms that a controller should be a personality with high, balanced levels of knowledge and practical experience, as well as communication and presentation skills.

Both groups of respondents have also given relatively high importance to language knowledge. However, in our opinion this is not valid generally; the result of the investigation has probably been influenced by the fact that many companies in the sample belong to 
multinational networks, and effective communication with supervisory management levels and other corporation members plays a relatively great importance.

The concrete results of the investigation are shown in Table 8.

Table 8. Selection of potential candidates for a controller position

\begin{tabular}{lcccc}
\hline In the process of a potential controller selection it is & \multicolumn{2}{c}{ "Should be" } & \multicolumn{2}{c}{ "Is" } \\
\cline { 2 - 5 } important to take into consideration & Average & Mode & Average & Mode \\
\hline Previous education & 4.17 & 5 & 4.03 & 4 \\
\hline Present practical experience & 4.38 & 5 & 4.50 & 5 \\
\hline Ability to deal with people and personality profile & 4.08 & 4 & 4.06 & 4 \\
\hline Communication abilities and skills & 4.33 & 5 & 4.04 & 4 \\
\hline ICT competencies & 3.67 & 3 & 3.75 & 4 \\
\hline Language knowledge & 3.57 & 3 & 3.44 & 4 \\
\hline
\end{tabular}

Source: authors' calculations.

The analysis of controllers' continuing professional development area has confirmed that both groups of experts consider this area to be quite important for the quality of controllers' activities.

The research also found that management generally enables the companies' controllers to take part in continuing professional development, especially if controllers actively search for the possibilities to educate themselves.

However, according to the second group of experts, company management does not always pay adequate attention to whether controllers enhance their professional competence in the cases when they are passive in this regard.

Both groups are also more or less unanimous in their opinion that controlling departments should consist of a stable team of experts which should not be changed very often.

Agreement of both groups of experts has also existed in their opinion that the remuneration of controllers is (should be) slightly higher in comparison with employees operating at the same organizational level.

The concrete results of this part of investigation are shown in Table 9.

Table 9. Controllers’ professional development

\begin{tabular}{lccccc}
\hline & \multicolumn{2}{c}{ "Should be" } & \multicolumn{3}{c}{ "Is" } \\
\cline { 2 - 6 } & Average & Mode & Average & Mode \\
\hline $\begin{array}{l}\text { Controlling department consists of a stable team of } \\
\text { experts who do not change very often }\end{array}$ & 3.75 & 3 & 4.11 & 4 \\
\hline $\begin{array}{l}\text { In comparison with employees operating at the same } \\
\text { organizational level, controllers are paid above average }\end{array}$ & 3.30 & 3 & 3.57 & 4 \\
\hline $\begin{array}{l}\text { Continuing professional development is quite important } \\
\text { for the quality of the controllers' work }\end{array}$ & 4.58 & 5 & 4.43 & 5 \\
\hline $\begin{array}{l}\text { Company management enables its controllers to } \\
\text { continue their professional development }\end{array}$ & 4.63 & 5 & 3.75 & 4 \\
\hline $\begin{array}{l}\text { Company management verifies whether controllers } \\
\text { enhance their professional competence }\end{array}$ & 4.17 & 5 & 2.76 & 3 \\
\hline
\end{tabular}

Source: authors' calculations. 


\subsection{Quality assurance of the controllers' activities}

The content and structure of those parts of the questionnaire which was devoted to quality assurance was derived from the preceding parts devoted to general and specific contents of controllers' activities and to their authority and responsibility.

Responses gained from this part generally confirm the necessity of regular evaluation of controllers' activities. Nevertheless, answers to the open question "How is the controllers' work evaluated?" were very general; for example: a vague explanation "the evaluation is carried out at a parent company level” was repeated in some responses.

In this regard, it is quite apparent that development of quality standards for controllers could enhance the general awareness of how to assure higher quality of the profession for a future; the results of this research could be used as one of the sources for their development.

The results of this part of investigation are stated in Table 10.

Table 10. Quality assurance of controllers’ work

\begin{tabular}{lcccc}
\hline & \multicolumn{2}{c}{ "Should be" } & \multicolumn{2}{c}{ "Is" } \\
\cline { 2 - 5 } & Average & Mode & Average & Mode \\
\hline $\begin{array}{l}\text { Controllers' work quality is regularly checked and } \\
\text { evaluated }\end{array}$ & 4.48 & 5 & 3.85 & 5 \\
\hline Controllers' work quality assurance includes & & & & \\
\hline$\quad$ Correctness of input data & 4 & 5 & 4.04 & 4 \\
\hline Information relevance & 4.67 & 5 & 3.87 & 4 \\
\hline$\quad$ Timeliness of rendered information & 4.52 & 5 & 3.54 & 4 \\
\hline Formal level of rendered information & 4.17 & 4 & 3.69 & 4 \\
\hline Neutrality and objectivity of information & 4.71 & 5 & 3.71 & 4 \\
\hline Information flexibility & 4.09 & 5 & 4.15 & 5 \\
\hline Information comparability and consistency & 4.67 & 5 & 4.04 & 4 \\
\hline
\end{tabular}

Source: authors’ calculations.

\section{Conclusions}

Although the outcomes of the project were based on a limited number of responses and investigated the situation in the Czech Republic only, they have already brought inspirations both in the area of conceptual ideas as well as the empirical research results.

Regarding general contributions of the empirical research results which are the principal subject of this paper, its content and structure have already contributed to a better understanding of the common features of and differences between

- The development of the controllers' / management accountants' profession in a different part of the globe; and

- The profiles and professional orientations of auditors and professional accountants in business and of controllers / management accountants.

The results of the empirical research can be also used as a solid outcome for the development of "Standards of good practice" which should contain:

- The aims, content and structure of pre-qualification education including requirements for the assessment of the required level of knowledge;

- The requirements for professional skills of these experts including how they can be acquired; 
- The ways in which it is possible to gain practical experience including the instruments, manners and methods of verification whether the experience has been accomplished;

- The aims, content, structure of realization and methods of efficient verification of controllers' / management accountants' continuing professional development; and

- A code of ethics as a principal document whose aim should be to enforce professional approaches, values and attitudes in the work of these experts.

Some specific suggestions which should be incorporated into the abovementioned "Standards of good practice" can also be derived from the research investigations:

- Controllers should act as the economic conscience of a company. They should be responsible primarily for the availability and transparency of the information rendered to managers; conversely, they should not be responsible primarily for the financial results of a company;

- Regarding education, financial accounting and reporting, management accounting and corporate finance knowledge are especially important for controllers' work;

- In the ICT area, controllers should be perceived mainly as users rather than originators and verifiers of processing and user quality of information systems;

- Regarding the area of professional skills and practical experience, it is necessary to develop pre-conditions for the development of communication skills, ability to deal with people and assert his/her opinions and presentation skills which seem to be the most important for controllers' work;

- The research has confirmed how important it is for a company to define, enhance, support and communicate effectively ethical principles and rules; unfortunately, the investigation has also shown relatively low level of their usage in practice; consequently, this aspect should be incorporated into the quality standards of the controllers' work since it is very important;

- The research has also confirmed that continuing professional development is quite important for the quality of all controllers' activities; in this regard, it is necessary to find ways so that managers not only enable controllers to deepen their competence in continuing professional development; they should also be more active in relation to controllers who are passive in this regard and they should support, and verify whether controllers enhance their competence continuously;

- Finally, the results of the section devoted to quality assurance of controllers' work confirm that it is necessary to regularly and consistently assess controller's work;

- Nevertheless, the answers to the open question "How is controllers' work evaluated?" have been very general; it this regard, they serve as a proof that to develop a basis for this evaluation is necessary. The above stated conclusions could serve as the first step for its development.

\section{Acknowledgment}

The article has been developed as one of the outcomes of the IGA project No. F1/4/2012 "The impact of business environment changes on the professional competence of company controllers and in the frame of institutional support of science No. VŠE IP100040.

\section{References}

Burns, J., Yazdifar, H. (2001), Trick or treats? Financial Management, March, pp. 33-35. Carruth, B. (2004), Management Accounting - what's new? Chartered Accountants Journal, September, pp. 29-30. 
CIMA (2000), Management Accounting. Official Terminology, London, Chartered Institute of Management Accountants.

CIMA (2008), Improving Decision Making in Organizations. The Opportunity to Reinvent Finance Business Partners, London, Chartered Institute of Management Accountants.

CIMA (2009), Management Accounting Tools for Today and Tomorrow, London, Chartered Institute of Management Accountants.

Grandlund, M., \& Lukka, K. (1998), Towards increasing business orientation: Finish management accountants in a changing cultural context, Management Accounting Research, No. 9, pp. 185-211.

Hoper, T. (1980), Role conflicts of management accountants and their position within organization structures, Accounting organization and Society, Vol. 31, pp. 129-55.

Horváth, P. (2006), Das Controllingkonzept. Der Weg zu einem wirkungsvollen Controllingsystem, München: DTV Verlag Valen Beck.

IFAC (2003), International Education Standards for Professional Accountants, New York: International Federation of Accountants.

International Group of Controlling (2010), Controller-Wörterbuch, Stuttgart: SchäfferPoeschle Verlag für Wirtschaft Steuern Recht.

International Group of Controlling (2011), Controller Process Model, Freiburg, Haufe Verlag.

Jablonsky, F. S., Keating, P. J., Heian, J. B. (2004), Business Advocate or Corporate Policeman, New York: Financial Research Foundation.

Kaplan, R., Cooper, R. (1998), Cost and Effect: Using Integrated Systems to Drive Profitability and Performance, Boston: Harvard Business School Press.

Král, B., Šoljaková, L. (2015), Professional competency requirements on controllers in the Czech Republic: An empirical study. International conference „Finance and performance of firms in science, education and practice“, Tomas Bata University in Zlín, April 23-24, 2015.

Král, B., Šoljaková, L. (2014), Requirements on controllers in the Czech Republic. An empirical study, Zeszyty Teoretyczne Rachunkowosci, 99, pp.151-175.

Merchant, K. (2003), Management control systems: performance measurement, evaluation and incentives, Harlow: Prentice Hall / Pearson Education.

Parker, L. (2002), Reinventing the management accountant, Transcript of CIMA address delivered at Glasgow University, 15 March.

Pierce, B., O'Deam, T. (2003), Management accounting information and the needs of managers: perceptions of managers and accountants compared, British Accounting Review, Vol. 35, No. 3, pp. 257-90.

Simons, R. (2004), Performance Measurement and Control Systems for Implementing Strategy, New Jersey: Prentice Hall.

UNCTAD (2011), Revised Model Accounting Curriculum [on-line], Geneva: United nations Conference on trade and Development.

Yasin, M. M., \& Bayes, P. E., Czuchry, A. J. (2005), Changing role of accounting in supporting the quality and customers goals of organizations: an open system perspectives, Journal of Management, Vol. 22, No. 3, pp. 322-31.

Zralý, M. (2007), Integration Concept of Management Control and its Contribution to Performance Management; in Proceedings of EIASM 4th Conference on Performance Measurement and Management Control, Nice. 